\title{
PROSES PENYUNTINGAN KAMUS PERTANIAN UMUM \\ DI PENERBIT PENEBAR SWADAYA
}

Selly Ayu Rhahmadani, Irene Maria Juli Astuti

Program Studi Penerbitan, Jurusan Penerbitan, Politeknik Negeri Media Kreatif Jakarta

\begin{abstract}
The purposes of this study are to describe the process of editing, the role of copyeditor, and the difficulty in editing the manuscript of "Kamus Pertanian Umum". The methods used are a study library, observation, and interviews. The results show that first, there is a difference house style for writing dictionaries in Penebar Swadaya and second, the role of copy editor is only involved in mechanical editing.
\end{abstract}

Keywords: editing, Kamus Pertanian Umum, copyeditor

\section{PENDAHULUAN}

Penyuntingan merupakan sebuah proses sunting terhadap naskah yang diperoleh dari penulis atau engarang dan prosesnya dilakukan oleh editor dan kopieditor di suatu penerbitan. Dalam dunia penerbitan, penyuntingan menjadi mata rantai kedua yang menentukan suksesnya sebuah buku setelah pengadaan naskah buku. Tanpa penyuntingan yang baik, sebuah naskah tidak mungkin menjadi buku yang menarik bagi para pembaca.

Keragaman naskah yang diterima penerbit dari sumber naskah (penulis, pengarang, dan juga bank naskah) merupakan sesuatu hal yang lumrah. Naskah yang diterima pun juga memiliki klasifikasi tertentu. Salah satu contoh, penerbit yang mengelola naskah pertanian tidak akan menerima naskah politik ataupun naskah sosial. Di dalam suatu penerbit biasanya ada yang memiliki sebuah imprint atau anak penerbit. Di sana naskah dapat dikelompokan sesuai klasifikasinya. Berbeda dengan imprint yang memiliki klasifikasi dalam penempatan naskah, pada kondisi ini kopieditor tidak dikhususkan di naskah tertentu. Kopieditor menerima berbagai macam naskah dan menyuntingnya berdasarkan penyuntingan mekanik, yang sebelumnya sudah dikerjakan editor ahli untuk penyuntingan substansi. Dalam kegiatannya, kopieditor yang tidak dibekali ilmu tertentu mengenai naskah terkait biasanya akan mengalami kesulitan untuk memahami suatu kalimat di dalamnya. Oleh karena itu, peran kopieditor seperti ini yang rentan akan kesalahan.

Gorys Keraf (2009), Kamus merupakan sebuah buku referensi yang memuat daftar kosa kata yang 
terdapat dalam sebuah bahasa. Yang disusun secara alfabetis disertai keterangan bagaimana menggunakan kosa kata itu.

Berdasarkan latar belakang masalah, identifikasi masalah, dan pembatasan masalah, perumusan masalah ini dirumuskan sebagai berikut. (1) Bagaimanana proses penyuntingan Kamus Petanian Umum di penerbit Penebar Swadaya? (2) Bagaimana peran kopieditor dalam penyuntingan Kamus Petanian Umum di penerbit Penebar Swadaya ? (3) Kendala apa saja yang terdapat dalam penyuntingan Kamus Pertanian Umum? Adapun tujuannya adalah untuk: (1) Menjelaskan proses penyuntingan Kamus Petanian Umum di penerbit Penebar Swadaya. (2) Menjelaskan kendala yang terdapat dalam proses penyuntingan Kamus Pertanian Umum.

Editing (penyuntingan)

merupakan proses yang dilakukan seorang editor untuk mengomunikasikan ide/gagasan para penulis/pengarang secara mudah, jelas, benar, serta tepat kepada pembaca dengan sasaran prinsip menebarkan ilmu dan informasi yang bermanfaat untuk publik. Menurut Bambang Trim (2005), editing adalah perpaduan antara keterampilan dan seni. Seseorang yang melakoninya paling tidak memiliki beberapa kecerdasan (mengutip teori multiple intelligences, Howard Gardner), seperti kecerdasan linguistik, kecerdasan visual, kecerdasan antarpersonal, dan kecerdasan intrapersonal.

KBBI (2008), Kata dasar sunting melahirkan bentuk turunan menyunting (kata kerja/verba), penyunting (kata benda/nomina), dan penyuntingan (kata benda/nomina). Kata menyunting bermakna (1) menyiapkan naskah siap cetak atau siap terbit dengan memperhatikan segi sistematika penyajian, isi, dan bahasa (menyangkut ejaan, diksi dan struktur kalimat); mengedit; (2) merencanakan dan mengarahkan penerbitan (surat kabar, majalah); (3) menyusun atau merakit (film, pita rekaman) dengan cara memotongmotong dan memasang kembali.

Pamusuk Eneste (2012), pengertian menyunting yang cocok dengan penerbitan buku adalah pengertian pertama, yaitu menyiapkan naskah siap cetak atau siap terbit dengan memperhatikan segi sistematika penyajian, isi, dan bahasa (menyangkut ejaan, diksi, dan struktur kalimat). Penyuntingan adalah sebuah proses, cara, perbuatan sunting-menyunting; segala sesuatu yang berhubungan dengan pekerjaan menyunting; pengeditan.

Orang yang menyunting naskah disebut penyunting naskah atau lazim disebut kopieditor. Sebagai kopieditor, penyuntingan naskah dibatasi secara mekanik saja atau yang biasa disebut oleh bidang editorial adalah mechanical editing. Mechanical editing adalah praktik penyuntingan dasar untuk memeriksa dan memperbaiki bagian naskah dari segi kebahasaan. Jenis 
penyuntingan ini menggunakan tanda-tanda koreksi yang dibubuhkan pada naskah secara manual.

Fokus Mechanical Editing 1). Ejaan; 2). Pemenggalan kata; 3). Huruf kapital; 4). Tanda baca; 5). Penerapan angka dan rumus; 6). Penerapan kutipan; 7). Penggunaan singkatan dan akronim; 8). Penggunaan huruf miring dan huruf tebal; 9). Penerapan elemen khusus (judul, daftar, tabel, grafik, dan diagram); 10). Format catatan kaki, catatan akhir, dan dokumentasi lain.

$$
\text { Mengutip dari buku }
$$

Pengelolaan Penerbitan Bukul

(1988),. Sebagian besar pekerjaan redaksi kantor itu terdiri atas penyuntingan naskah, sebagai berikut: 1) Pemeriksaan struktur dan logika 2) Pemeriksaan dalam penggunaaan bahasa 3) Bila perlu menulis dan mengetik kembali 4) Pemeriksaan ejaan dan tanda baca 5) Penyiapan produksi (menyiapkan menjadi siap cetak).

$\begin{array}{lll}\text { Lebih lanjut Bambang } & \text { Trim } \\ \text { (2005) } & \text { menjelaskan dunia }\end{array}$
penyuntingan naskah buku, secara standar ada tujuh aspek yang disunting, yaitu: 1) Readablity (keterbacaan) dan Legibility (kejelasan) 2) Konsistensi atau ketaatasasan 3) Tata bahasa atau kebahasaan 4) Gaya bahasa 5) Ketelitian data dan fakta 6) Legalitas dan kesopanan 7) Rincian produksi (spesifikasi produk). Ketujuh aspek ini menjadi fokus perhatian seorang kopieditor yang secara teknis dilakukan secara mechanical editing dan substantive editing. Mechanical editing termasuk kategori penyuntingan ringan, sedangkan substantive editing termasuk kategori penyuntingan berat. Herman Holtz, penulis buku how to Start dan Run an Editing Business, menyatakan sangat tipis perbedaan antara penyuntingan berat dan penulisan ulang. Editing adalah aktivitas yang menggunakan otak kiri dan kanan sekaligus. Karena itu, seorang editor yang andal akan memiliki IQ, EQ, sekaligus SQ yang tinggi.

Bambang Trim (2009), Ada tiga pembagian besar naskah yang ditulis dalam Buku Taktis Menyunting Buku yaitu, fiksi, nonfiksi, dan faksi.Fiksi adalah naskah berbasiskan khayalan atau imajinasi, seperti fiksi sains, fiksi horor, dan fiksi komedi. Pencipta fiksi kerap disebut pengarang (author) dan terkadang menggunakan nama pena atau nama samaran. Nonfiksi adalah naskah yang berbasiskan data atau fakta sebenarnya, seperti karya ilmiah, ilmiah populer, reportase, ataupun panduan petunjuk melakukan sesuatu. Pencipta nonfiksi kerap disebut penulis (writer) atau penyusun. Faksi adalah nonfiksi yang disajikan mirip dengan fiksi atau dikisahkan. Faksi merupakan kisah berdasarkan data dan fakta sebenarnya sehingga tidak merupakan khayalan, apalagi imajinasi. Naskah yang tergolong faksi adalah mamoar, biografi, dan autobiografi. Kategori yang kaitannya sesuai dengan naskah Pertanian adalah naskah nonfiksi, 
naskah yang berbasiskan data atau fakta sebenarnya.

$$
\text { Pamusuk Eneste (2012), }
$$
memaparkan bahwa terdapat dua belas ragam naskah yang disebutkan dalam bukunya Buku Pintar Penyuntingan Naskah, yaitu: 1) naskah fiksi; 2) naskah sastra; 3) naskah buku sekolah; 4) naskah bacaan anak; 5) naskah perguruan tinggi; 6) naskah musik; 7) naskah matematika, fisika, kimia; 8) naskah biologi; 9) naskah kamus; 10) naskah ilmiah; 11) naskah ilmiah populer; dan 12) naskah terjemahan. Dari dua belas naskah yang telah disebutkan di atas, jenis naskah yang sesuai dengan penulisan karya Tugas Akhir ini adalah naskah kamus.

Lebih lanjut dijelaskan Pamusuk Eneste, bahwa naskah kamus memiliki kekhususan tersendiri. Pertama, dilihat dari segi layout-nya, kamus berbeda dengan ragam naskah lain. Buku kamus biasanya dibagi dalam dua kolom dan antara lajur kiri dan lajur kanan dibatasi oleh garis vertikal (ada juga yang tidak memakai garis pembatas). Kedua, entri (lema) kamus biasanya diberi penjelasan (deskripsi) secara singkat. Ini tentu beda dengan naskah ragam lain yang di dalamnya penulis yang mempunyai peluang untuk berpanjang-lebar memberikan penjelasan. Ketiga, entri kamus biasanya dimulai dengan huruf kecil (onder-kast). Keempat, naskah kamus biasanya berisi singkatangsingkatan yang lazim dipakai dalam dunia perkamusan.

Berbeda dengan seorang editor (khususnya editor senior) yang sering keluar kantor (untuk mencari naskah dan menghubungi calon pengarang atau penulis), seorang penyunting naskah dituntut banyak berada di kantor atau di ruangan. Di samping itu, penyunting naskah pun tidak ikut mencari naskah dan mempertimbangkan naskah. Tugas penyunting naskah dapat diperinci sebagai berikut ini: (1) menyunting naskah dari segi kebahasaan (yaitu ejaan, diksi, struktur kalimat); (2) menyunting naskah sesuai dengan gaya selingkung penerbitan dan menjaga konsistensi naskah; (3) memperbaiki naskah dengan persetujuan penulis atau pengarang; (4) membuat naskah enak dibaca dan tidak membuat pembaca bingung (memperhatikan keterbacaan naskah); (5) membaca dan mengoreksi cetak coba (pruf).

\section{METODE PENELITIAN}

Metode yang digunakan dalam penulisan Tugas Akhir ini, yaitu metode studi pustaka, observasi, dan wawancara. Dalam semua metode ini menjelaskan proses penyuntingan dalam revisi Kamus Pertanian Umum ketika Penulis melakukan kegiatan Praktik Industri di Penerbit Penebar Swadaya sebagai kopieditor. Hal ini merupakan salah satu tujuan Penulis dalam upaya menambah kelengkapan dan pengumpulan data. Berikut adalah uraian dari metode yang digunakan penulis: (1) Studi Pustaka. Penyusunan Tugas Akhir sebagian besar berdasarkan dari beberapa sumber literatur, baik 
berupa bahan kuliah, buku-buku mengenai penyuntingan buku, bukubuku yang membahas mengenai proses penyuntingan dan peran kopieditor, serta ragam naskah guna mendukung penjelasan teori pembahasan. (2) Metode observasi dilakukan saat melakukan kegiatan Praktik Industri selama tiga bulan di penerbit Penebar Swadaya. Kegiatan tersebut bertujuan untuk mengumpulkan data yang mendukung landasan teori dan memahami lebih mengenai proses penyuntingan Kamus Pertanian Umum di penerbit Penebar Swadaya. (3) Metode wawancara ini dilakukan dengan praktisi di Penerbit Penebar Swadaya dan dosen PoliMedia guna mendapatkan informasi mengenai pembahasan hal-hal yang terkait dalam kepentingan penyusunan Tugas Akhir.

\section{HASIL PEMBAHASAN}

\section{Naskah Kamus Pertanian Umum}

a. Naskah Kamus

Naskah Kamus Pertanian

Umum merupakan naskah pertanian yang diterbitkan Penebar Swadaya untuk orang-orang di bidang terkait sebagai acuan atau referensi. Naskah ini dibuat sebagaimana sebelumnya yang sudah ada, kemudian direvisi dalam upaya memperbarui istilahistilah asing yang baru ditemui dan ditetapkan. Pembuatan buku ini disesuaikan dengan gaya selingkung penerbit.

b. Identitas Buku

Judul Buku : Kamus Pertanian

\section{Umum}

Penulis : Tim Penulis PS

Jenis naskah : Naskah Pertanian

Jumlah halaman : 434 halaman

Ukuran buku : 15 x $23 \mathrm{~cm}$

Foto Sampul : J. Sugito

Ilustrator : J. Sugito

Penerbit : Penebar Swadaya, anggota Ikapi

Perum Bukit Permai,

Jl. Kerinci BLok A2 RW 11 No. 23-

24

Cibubur, Jakarta Timur, 13720

Telp. (021) 29617008, -009, -010

Faks. (021) 8721570

Pemasaran : Niaga Swadaya

Jl. Gunung Sahari III/7, Jakarta 10610

Telp. (021) 4204402, 4255354

c. Segi Fisik Buku

Segi fisik adalah segi tampilan dari luar buku, dapat dinilai dari jenis kertas, ukuran buku, jumlah halaman, serta penggunaan warna pada buku. (1) Jenis kertas yang digunakan untuk halaman kulit depan adalah AC 210 gram dan isi menggunakan HVS 70 gram. Jenis kertas ini adalah jenis kertas yang umumnya sering digunakan pada buku pelajaran di Penerbit Penebar Swadaya. (2) Ukuran buku yang digunakan adalah $15 \times 23 \mathrm{~cm}$. Pemakaian ukuran tersebut lebih efisien karena meminimalisir banyaknya kertas yang terbuang saat di cetak dan mempengaruhi tata letak bagian isi dan jumlah halaman. (3) Untuk warna pada sampul buku menggunakan tinta berwarna, dengan dominan warna hijau, karena 
menunjukan tema pertanian yang melekat dengan isi buku tersebut.
Sedangkan untuk isi buku menggunakan warna hitam-putih.

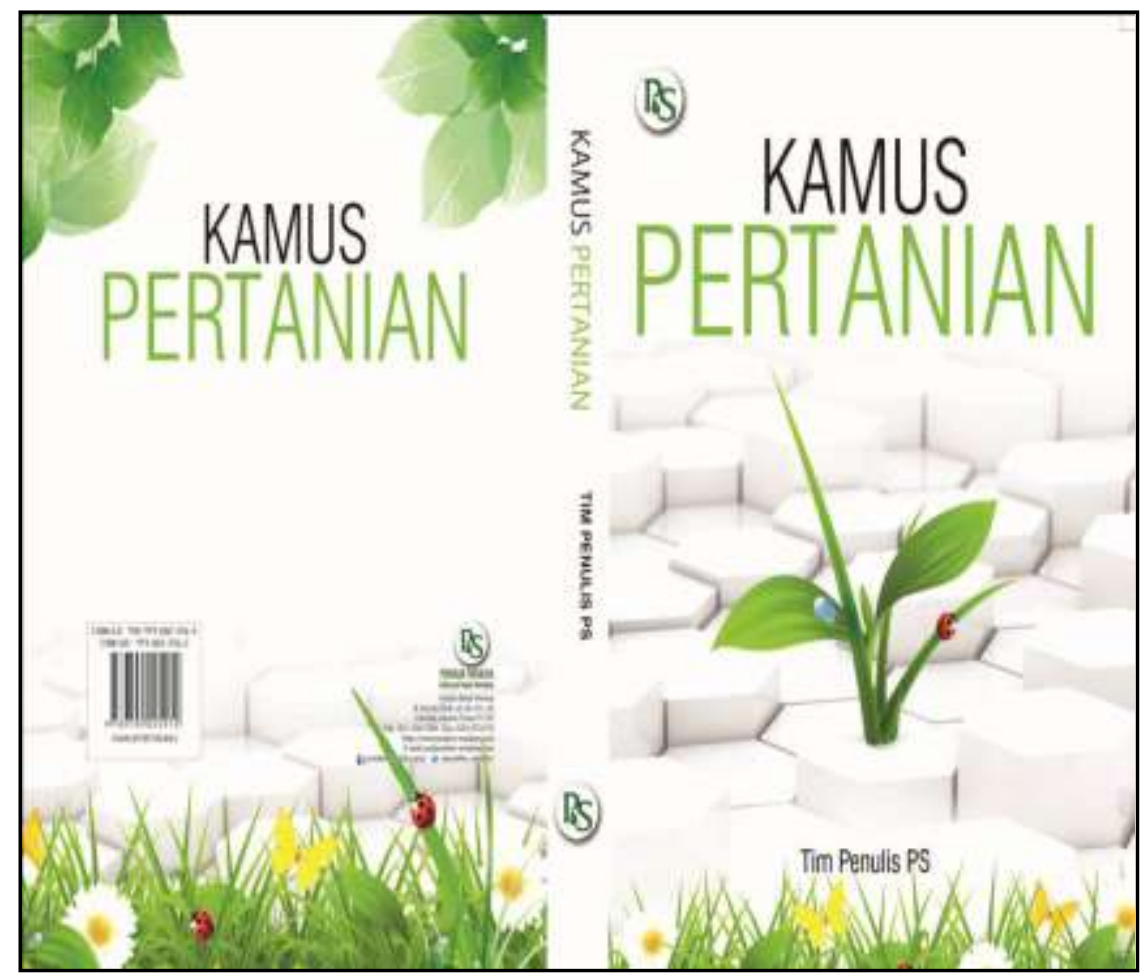

Gambar 1 Sampul kamus pertanian umum

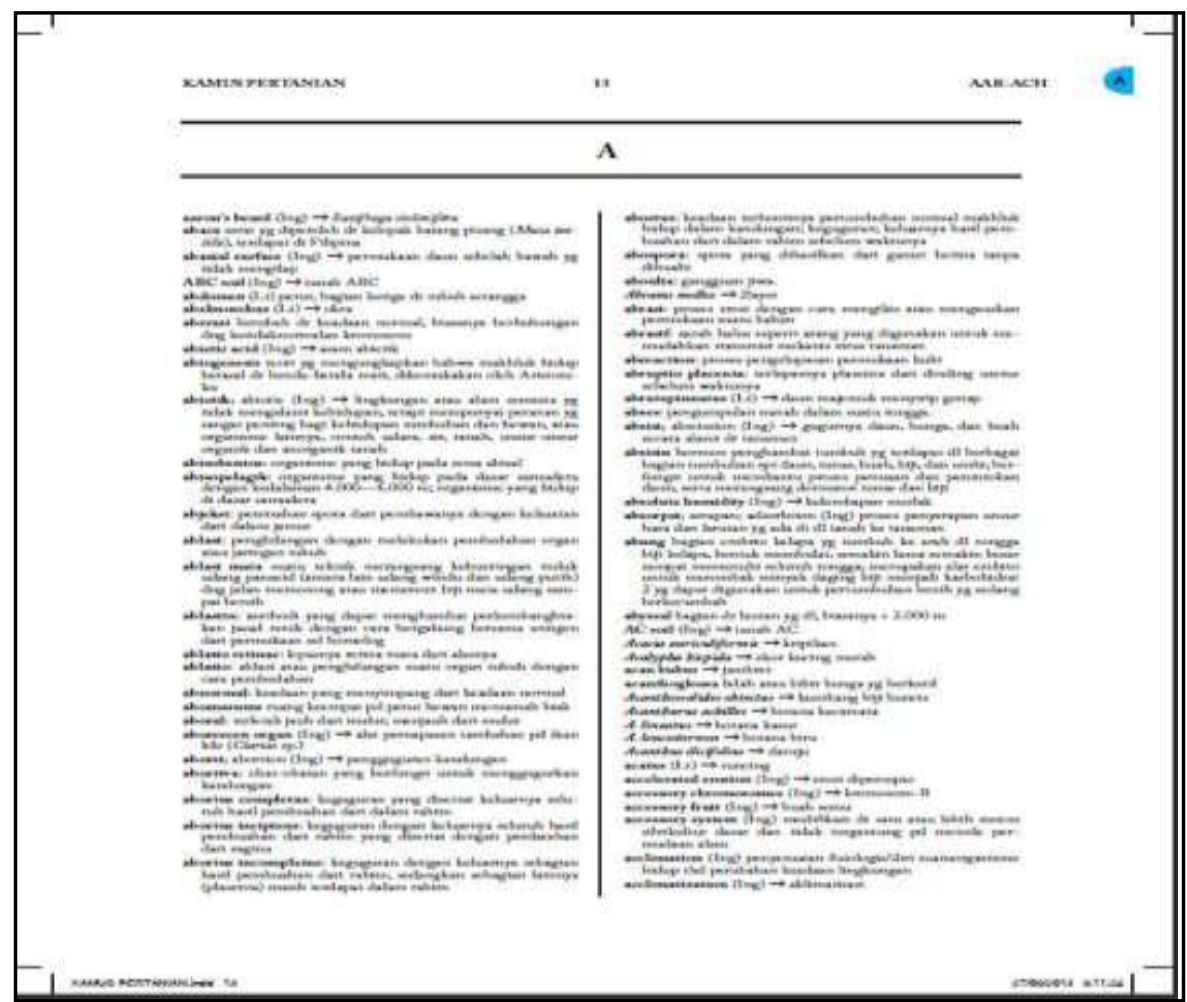

Gambar 2 Halaman isi Kamus Pertanian Umum 


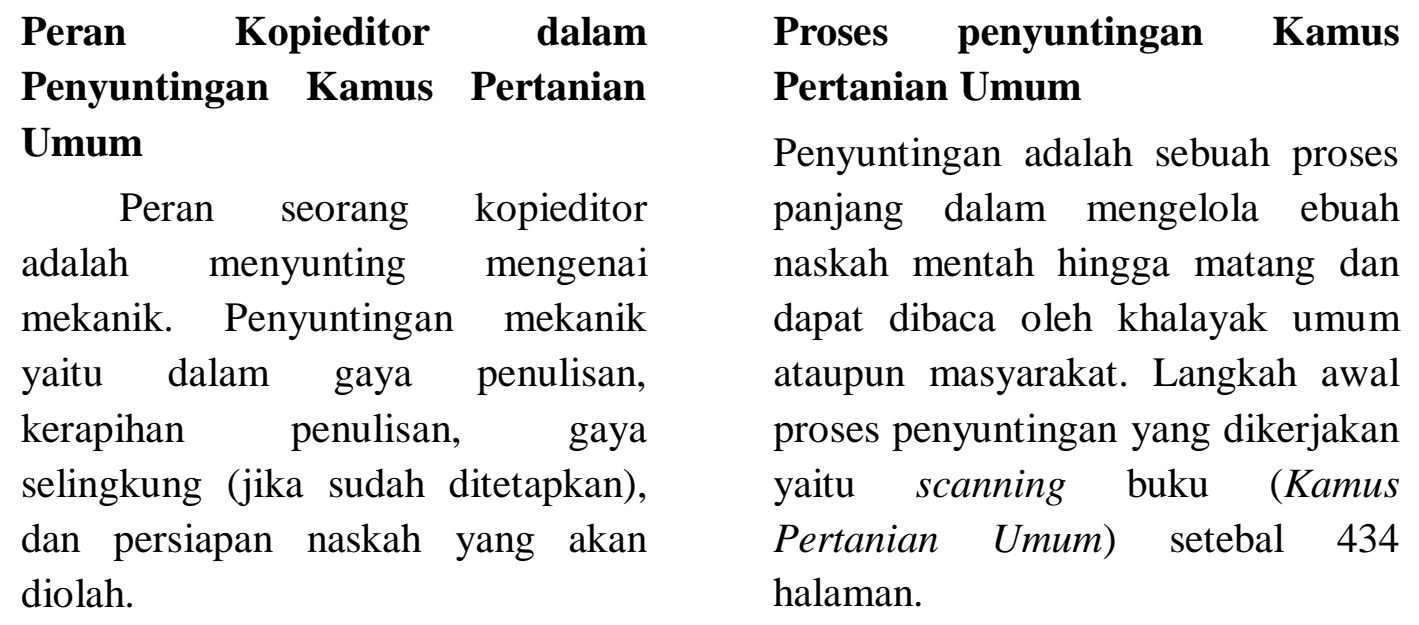

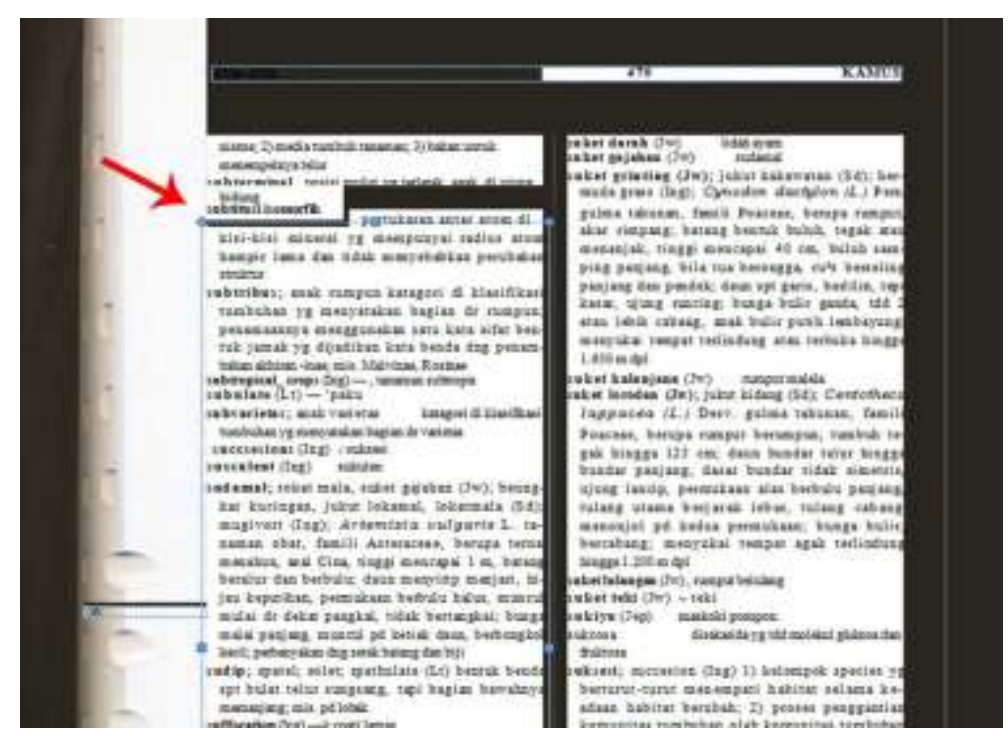

Gambar 4 Hasil scan rusak

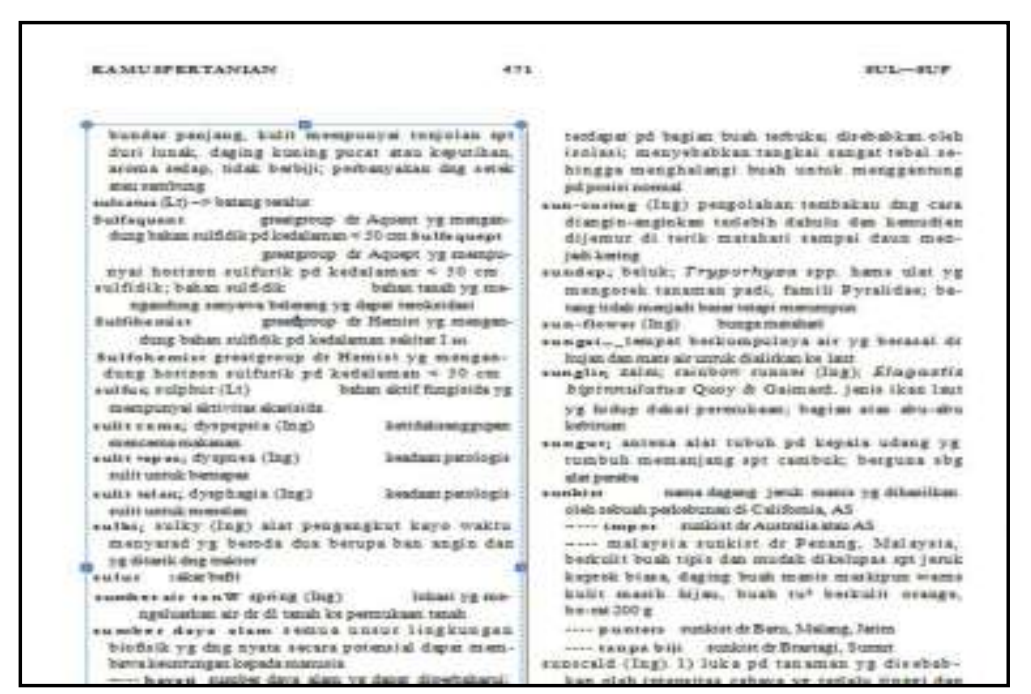

Gambar 5.Hasil scan rapi 
Hal tersebut dilakukan karena bahan baku atau naskah yang akan disunting merupakan naskah lama yang sudah tidak ada data softcopy untuk direvisi. Seperti halnya pada Gambar 4, hasil scan tepotongpotong atau rusak. Solusinya yaitu melakukan scaning ulang pada halaman ke dalam bentuk teks atau format *.doc

(1) Software yang digunakan untuk scanning Kamus Pertanian Umum yaitu Omnipage 4. Omnipage merupakan salah satu software word processor dengan memanfaatkan scanner sebagai media pembaca yang ditransfer menjadi file word (*.txt, *.rtf, *.doc). Omnipage merubah file gambar $\left(^{*} . j p g\right)$ menjadi teks. Omnipage memiliki kemampuan mengonversi teks, tabel, dan gambar ke dalam bentuk $M s$. Word, Ms. Excell, Ms. Power Point, dan $P D F$. Naskah yang sudah rapih dalam bentuk teks, dari segi mechanical editing, siap untuk diolah selanjutnya. Seperti pada gambar di bawah ini

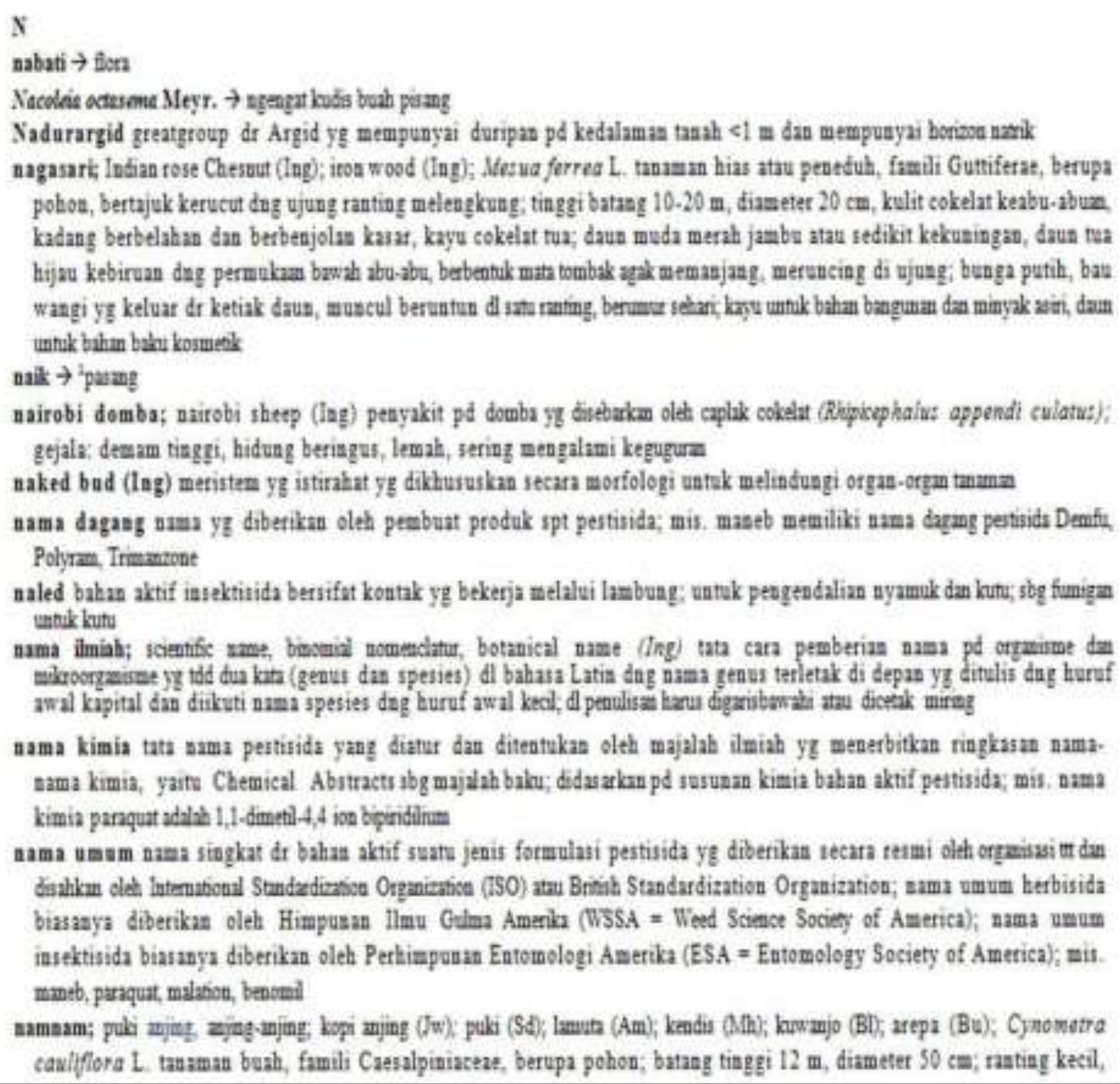

Gambar 6 Naskah rapi siap olah

2) Microsoft Word atau Microsoft

Office Word (Ms.Word) adalah perangkat lunak pengolah kata yang digunakan penulis untuk merapihkan naskah mentah. Sebelum memasuki proses penataletakkan buku Kamus 
Pertanian Umum, naskah mentah pada awalnya berbentuk Ms. Word yang sudah dirapihkan terlebih dahulu dengan format *.doc. Lalu, dipindahkan ke perangkat lunak lain, seperti Adobe Indesign untuk dilayout. Setelah pengelolaan pada naskah cetak Kamus Pertanian Umum selesai, penulis juga sempat mengerjakan penggabungan isi. Data dari Kamus Biologi yang diterima setelah itu berupa softcopy, kemudian digabungkan dengan data dari Kamus Pertanian Umum. Kedua kamus ini merupakan terbitan dari penerbit Penebar Swadaya. Berikut adalah gambar naskah mentah setelah proses penggabungan data :

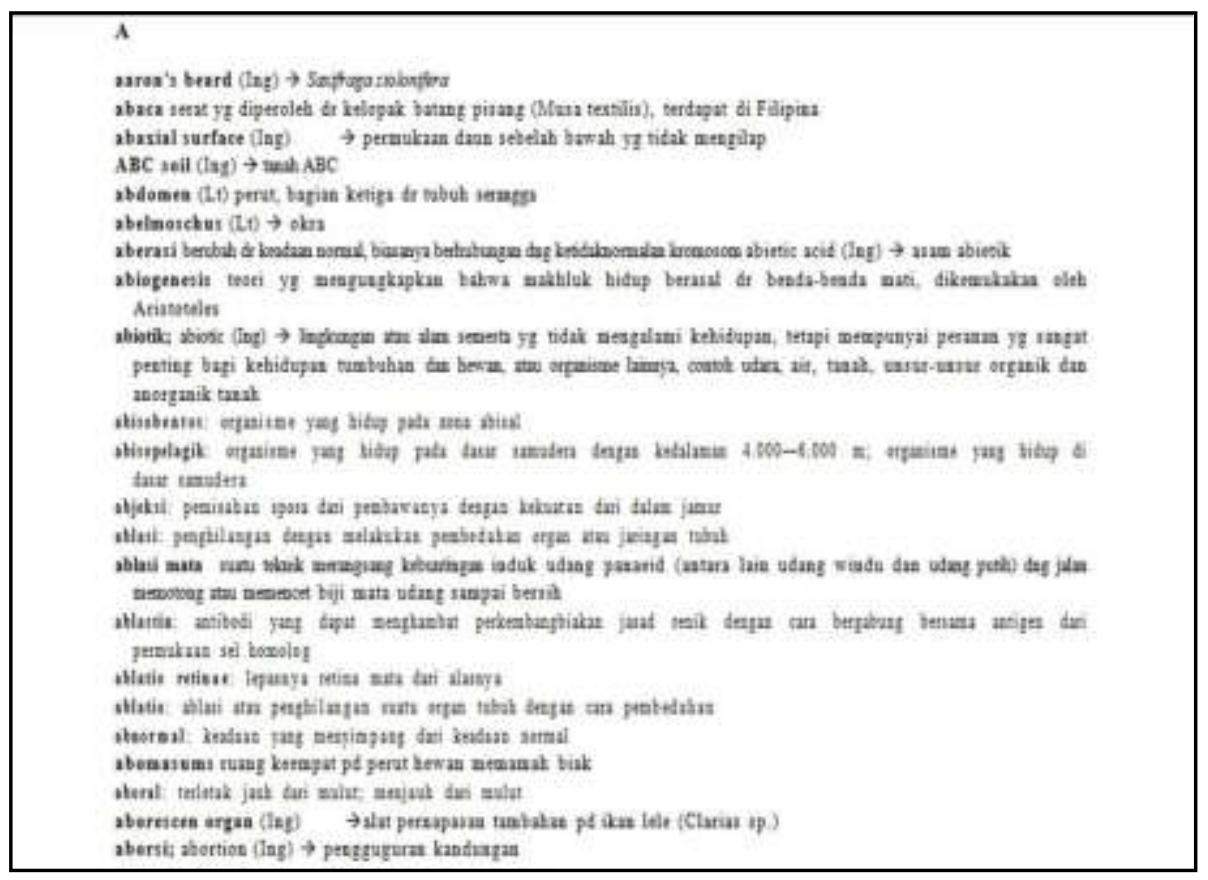

Gambar 7 Naskah setelah penggabungan data

\section{Pembahasan Perbedaan Gaya Penulisan}

Terdapat dua perbedaan gaya penulisan dalam Kamus Pertanian Umum yang ditemukan Penulis sebagai kopieditor di Penerbit Penebar Swadaya, seperti:

a. Perbedaan Gaya Penulisan dengan Kamus Besar Bahasa Indonesia (KBBI) dapat dilihat pada Tabel 1. b. Perbedaan Gaya Penulisan dengan
Kamus Biologi. Kedua kamus ini merupakan terbitan dari penerbit Penebar Swadaya. Namun, pada gaya penulisannya terdapat perbedaan karena perbedaan waktu (sebelum penetapan gaya selingkung) dan editor yang menangani kedua kamus. Perbedaan gaya penulisan antara Kamus Pertanian Umum dengan Kamus Biologi dapat dilihat pada Tabel 2. 
Tabel 1 Perbedaan gaya penulisan dengan KBBI

No

Gaya Penulisan

\section{Kamus Pertanian (KPU)}

1. Memakai kata entri untuk setiap istilah baru.

2. Gaya tata letak pada penulisan petunjuk kamus memakai dua kolom pada satu halamannya

3. Adanya tanda titik dua (:) di setiap akhir istilah (entri) jika istilah tersebut berasal dari bahasa indonesia bukan istilah asing.

4. Tidak disertai contoh kalimat dari istilah (entri) terkait.

5. Tanda titik koma (;), apabila entri memiliki nama lain, baik nama daerah maupun nama asing.

Co: Acrocylindrium oryzae; Sarocladium oryzae cendawan penyebab penyakit busuk pelepah pd tanaman padi

6. Penulisan entri dan uraiannya diawali dengan huruf kecil, kecuali untuk istilah (entri) nama jenis dengan penulisan istilah Latin dicetak dengan huruf awal kapital sesuai dengan cara penulisannya.
Kamus Besar Bahasa Indonesia

(KBBI)

Memakai kata lema untuk setiap istilah baru.

Gaya tata letak pada penulisan petunjuk kamus memakai satu halaman tanpa dibuat kolom.

-Tidak adanya tanda titik dua (:) di setiap akhir istilah (lema).

-Titik dua (:) dipakai sebagai pengganti kata misalnya di akhir deskripsi dan sebelum contoh pemakaian.

Disertai contoh kalimat untuk istilah (lema) terkait.

-Tanda titik koma (;) dipakai untuk memisahkan bentuk kata yang bermakna sama/hampir sama (sinonim) yang terdapat pada penjelasan makna.

Co: salah guna, menyalahgunakan $v$ melakukan sesuatu tidak sebagaimana mestinya; menyelewengkan

-Titik koma (;) dipakai sebagai penanda akhir penjelasan makna

sebuah sublema yang masih belum merupakan bentuk derivasi

terakhir (penjelasan makna sublema yang merupakan bentuk

derivasi terakhir sebuah lema tidak diakhiri dengan tanda apa pun).

*derivasi: kata turunan, kata ulang, dan gabungan kata.

-Penulisan label kelas kata dan contoh

kalimat dari istilah (lema) terkait dicetak miring.

-Semua istilah (lema-sublema) diawali

dengan huruf kecil. 


\section{No Gaya Penulisan}

Kamus Pertanian (KPU)

Kamus Besar Bahasa Indonesia

(KBBI)

sedangkan penulisan entri untuk

nama jenis dengan istilah Latin

dicetak tebal-miring, sedangkan

istilah (entri) lainnya dicetak tebal-

tegak.

7. Terdapat label nama negara di Terdapat label kelas kata, maka setiap setiap istilah (entri).

Co: adas; dille (Bld); dill (Ing); .......

*Bld: Belanda

Ing: Inggris istilah (lema) memiliki keterangan kelas kata, seperti $a d v, a, n$, num, $p$, dan lain-lain.

Co: aba $n$ ayah; bapak;

8. Apabila sebuah entri memiliki Huruf yang dicetak tebal uraian lebih dari satu dan menunjukkan angka untuk angka antara uraian tersebut memiliki arti yang berbeda, tetapi polisemi (kata yg memiliki lebih dari satu makna).

masih memiliki kaitan yang erat (polisemi), maka pembatasannya diberi nomor dan kurung tutup di akhir angka.

Co: lignin 1) unsur pokok dinding sel tanaman berkayu yg memerlukan komposisi bahan kimia yg masih belum diketahui; 2) bagian serat .....

9. Sub-entri ditulis di bawah entri utama dengan menggunakan tanda (----), sedangkan sub-subentri Co: sabar $a \mathbf{1}$ tahan menghadapi cobaan (tidak lekas marah, tidak lekas putusasa, tidak lekas patah hati); tabah: hidup ini dihadapinya --; 2 tenang; .... ditulis di bawah sub-entri dengan menggunakan tanda (-- --), dan seterusnya.

Co: reaksi; perubahan yg terjadi akibat suatu gejala atau peristiwa

---- tanah; soil reaction (Ing) reaksi yg terjadi dl tanah ......

-Gabungan kata atau kelompok kata yang tidak berderivasi di perlakukan sebagai sublema. Letaknya langsung di bawah lema yang berkaitan dan disusun berderet ke samping secara berurutan menurut abjad. Unsur pertama gabungan kata itu dicetak dengan tanda hubung ganda (--).

Co: sagu $n 1$ pohon yg hati batangnya dapat dibuat tepung; ......

-- belanda garut; Maranta arundinacea; -betawi sagu belanda;

-Tanda hubung ganda (--) dipakai untuk menggantikan lema yamg terdapat dalam contoh kalimat atau gabungan kata.

Co: sabar $a 1$ tahan menghadapi cobaan 


\section{No Gaya Penulisan}

Kamus Pertanian (KPU) Kamus Besar Bahasa Indonesia

(KBBI)

\begin{tabular}{ll}
\hline & (tidak lekas marah, tidak lekas putus asa, \\
& tidak lekas patah hati); tabah: hidup ini \\
& dihadapinya --; \\
\hline 10. Tidak ada tanda garis miring & Garis miring (/.../) dipakai untuk lafal \\
& kata yang mengandung unsur \\
& bunyi /e/ atau /é/ agar tidak terjadi \\
& kesalahan di dalam melafalkan \\
& kata. \\
& Co: sensor /sénsor/n pemeriksaan sesuatu spt \\
berita .... \\
\hline
\end{tabular}

Tabel 2 Perbedaan gaya penulisan dengan Kamus Biologi

\begin{tabular}{|c|c|c|}
\hline No & Kamus Pertanian Umum (KPU) & Kamus Biologi \\
\hline 1. & $\begin{array}{l}\text { Menggunakan tanda titik koma (;) } \\
\text { setelah awal kata, lalu diikuti } \\
\text { penjelasan. }\end{array}$ & $\begin{array}{l}\text { Menggunakan tanda titik dua (:) pada } \\
\text { awal kata, lalu diikuti penjelasan. }\end{array}$ \\
\hline 2. & $\begin{array}{l}\text { Mendahulukan istilah yang terdiri } \\
\text { dari satu kata dibanding istilah dua } \\
\text { kata dengan kata awal yang sama. } \\
\text { Co: Batang } \\
\text { Batang kayu }\end{array}$ & $\begin{array}{l}\text { Mendahulukan istilah dua kata } \\
\text { dibanding istilah satu kata dengan } \\
\text { kata awal yang sama. } \\
\text { Co: Batang kayu } \\
\text { Batang }\end{array}$ \\
\hline 3. & $\begin{array}{l}\text { Kalimat penjelas tidak diakhiri titik } \\
\text { (.) }\end{array}$ & Kalimat penjelas diakhiri titik (.) \\
\hline 4. & $\begin{array}{l}\text { Sub-entri dari satu istilah ditulis di } \\
\text { bawahnya dengan tanda (----) }\end{array}$ & $\begin{array}{l}\text { Sub-entri dari satu istilah tidak ditulis } \\
\text { dengan menggunakan tanda (----), } \\
\text { namun ditulis pada entri berikutnya. }\end{array}$ \\
\hline 5. & $\begin{array}{l}\text { Menggunakan sub-sub-entri yang } \\
\text { ditulis dengan menggunakan tanda } \\
(---) \text {. }\end{array}$ & Tidak ada sub-sub-entri. \\
\hline
\end{tabular}

\section{Kendala dan Solusi dalam Proses Penyuntingan}

Adapun kendala yang ditemukan penulis dalam proses penyuntingan Kamus Pertanian Umum di Penerbit Penebar Swadaya, antara lain: (a) Data atau naskah berupa softcopy yang akan direvisi tidak ada, karena itu kopieditor diminta untuk melakukan scanning buku terlebih dahulu. (b) Perbedaan penulisaan kamus saat penggabungan Kamus Petanian Umum dengan Kamus IPA khususnya Biologi, sehingga menyulitkan kopieditor untuk sekedar copy-paste, jadi 
diharuskan untuk penulisan ulang sesuai penulisan Kamus Pertanian Umum. (c) Diharuskan scanning ulang ketika hasil scan tidak maksimal atau tidak terbaca jelas di PC (Personal Computer), sehingga sulit untuk merapihkannya ke dalam bentuk teks. (d) Adanya perbedaan penulisan dengan Kamus Besar Bahasa Indonesia (KBBI) sehingga kopieditor kesulitan untuk mengikuti gaya penulisan yang akan dianut. (e) Tidak ada kopieditor sebelumnya yang mengerjakan pekerjaan ini, sehingga penulis sulit dalam mengajukan pertanyaan mengenai proses penyuntingan.

Keterbatasan pengetahuan dalam ilmu pertanian yang dapat menyebabkan terjadinya kesalahan penyuntingan atau tidak terlihatnya kesalahan pada konten naskah.

\section{Fakta-fakta antara Kenyataan dengan Teori}

Adapun fakta-fakta yang penulis temukan dalam proses penyuntingan Kamus Pertanian Umum di penerbit Penebar Swadaya, antara lain:

1 Adanya scanning naskah sebelum proses penyuntingan berlangsung.

2 Adanya perbedaan penulisan kamus yang diterbitkan oleh satu penerbit.

3 Belum adanya gaya selingkung untuk penulisan kamus di penerbit ini.

\section{PENUTUP}

Berdasarkan observasi dan studi pustaka yang dilakukan penulis, maka dapat disimpulkan bahwa isi sebuah buku tidak lepas dari kerja keras dari semua pihak, khususnya bidang editorial dalam tema ini. Bidang editorial pula yang menentukan gaya selingkung pada penerbit, lalu disesuaikan dengan jenis terbitan. Hal itu bertujuan untuk mengenalkan kepada pembaca bahwa terdapat identitas penerbit dalam produk terbitannya. Tujuan itu bisa dicapai salah satunya dengan gaya penulisan pada buku.

Simpulan lain yang didapat oleh penulis dalam Tugas Akhir ini, sebagai berikut:

(1) Pada proses penyuntingan Kamus Pertanian Umum, Penulis tidak terlibat dalam penentuan desain tata letak dan hal lainnya. Penulis hanya terlibat pada pengelolaan naskah dari segi mechanical editing. Prosesnya dimulai dalam bentuk cetak hingga dalam format *.doc pada Ms. Word setelah dilakukan scanning dan pengoreksian naskah on screen.

(2) Kendala yang dihadapi pada proses penyuntingan naskah Kamus Pertanian Umum, yaitu terdapat perbedaan gaya penulisan sehingga kopieditor kesulitan untuk mengikuti gaya penulisan yang akan dianut, rusaknya hasil scan dapat memperlambat proses on screen editing, dan keterbatasan pengetahuan dalam ilmu pertanian yang dapat 
menyebabkan terjadinya kesalahan penyuntingan atau tidak terlihatnya kesalahan pada konten naskah.

(3) Proses penyuntingan yang dikerjakan Penulis ini merupakan salah satu peran yang cukup membantu di bidang editorial. Peran Penulis sebagai kopieditor dapat dikatakan sebagai penghubung dalam rantai kerja penerbitan.

\section{DAFTAR RUJUKAN}

Andriese, H. G. CS. 1988. Pengelolaan Penerbitan Buku: Dari naskah menjadi buku. Jakarta: Pusat Grafika Indonesia - Depdiknas.

Eneste, Pamusuk. 2012. Buku Pintar Penyuntingan Naskah. Jakarta: PT Gramedia Pustaka Utama.

Keraf, Gorys. 2009. Diksi dan Gaya Bahasa. Jakarta: Gramedia Pustaka Utama
Riyadi, Noor \& Tri Manganingsih. 2006. Profesi di Penerbitan:

Deskripsi Jabatan dan Kompetensi di Penerbitan. Jakarta: Pusat Grafika Indonesia - Depdiknas

Tim Penyusun Kamus Pusat Pembinaan dan Pengembangan Bahasa. 2001. Kamus Besar Bahasa Indonesia. Edisi ketiga. Jakarta: Balai Pustaka.

Tim Penyusun Kamus Pusat Pembinaan dan Pengembangan Bahasa. 2008. Kamus Besar Bahasa Indonesia. Edisi keempat. Jakarta: Balai Pustaka.

Trim, Bambang. 2005. Memahami Copyediting: Pengantar dan Aplikasi Praktis Editing Naskah untuk Penerbitan Buku. Jakarta: IKAPI DKI Jakarta.

Trim, Bambang. 2009. Taktis Menyunting Buku. Jakarta: Maximalis. 